\title{
ICDP workshop on scientific drilling of Nam Co on the Tibetan Plateau: 1 million years of paleoenvironmental history, geomicrobiology, tectonics and paleomagnetism derived from sediments of a high-altitude lake
}

\author{
Torsten Haberzettl ${ }^{1}$, Gerhard Daut ${ }^{2}$, Nora Schulze ${ }^{3}$, Volkhard Spiess ${ }^{3}$, Junbo Wang ${ }^{4}$, Liping Zhu ${ }^{4}$, and \\ the 2018 Nam Co workshop party ${ }^{*}$ \\ ${ }^{1}$ University of Greifswald, Institute of Geography and Geology, Physical Geography, \\ Friedrich-Ludwig-Jahn-Str. 16, 17489 Greifswald, Germany \\ ${ }^{2}$ Friedrich-Schiller-University Jena, Institute of Geography, Physical Geography, \\ Löbdergraben 32, 07743 Jena, Germany \\ ${ }^{3}$ Department of Geosciences, Marine Technology and Environmental Research, \\ University of Bremen, Bremen, Germany \\ ${ }^{4}$ Institute of Tibetan Plateau Research, Chinese Academy of Sciences, No. 16 Lincui Road, \\ Chaoyang District, Beijing 100101, China \\ *A full list of authors and their affiliations appears at the end of the paper.
}

Correspondence: Torsten Haberzettl (torsten.haberzettl@uni-greifswald.de)

Received: 10 September 2018 - Revised: 21 November 2018 - Accepted: 22 November 2018 - Published: 12 June 2019

\begin{abstract}
The Tibetan Plateau is of peculiar societal relevance as it provides freshwater from the so-called "Water Tower of Asia" to a large portion of the Asian population. However, future climate change will affect the hydrological cycle in this area. To define parameters for future climate change scenarios it is necessary to improve the knowledge about thresholds, timing, pace and intensity of past climatic changes and associated environmental impacts. Sedimentary archives reaching far back in time and spanning several glacial-interglacial cycles such as Nam Co provide the unique possibility to extract such information. In order to explore the scientific opportunities that an ICDP drilling effort at Nam Co would provide, 40 scientists from 13 countries representing various scientific disciplines met in Beijing from 22 to 24 May 2018. Besides paleoclimatic investigations, opportunities for paleomagnetic, deep biosphere, tectonic and paleobiological studies were discussed. After having explored the technical and logistical challenges and the scientific opportunities all participants agreed on the great value and need to drill this extraordinary archive, which has a sediment thickness of more than $1 \mathrm{~km}$, likely covering more than $1 \mathrm{Ma}$.
\end{abstract}

1

With a mean elevation of $>4000 \mathrm{~m}$ above sea level, the Tibetan Plateau is often considered as the "Third Pole", as it is the third largest storage of ice on earth (Qiu, 2008). Its isolated setting at high altitudes resulted from its long tectonic evolution and made it home to unique ecosystems with a large number of endemic species, particularly in aquatic systems (von Oheimb et al., 2011). The Tibetan Plateau is also of peculiar social relevance as it is the source of several major rivers, providing freshwater from the so-called "Water Tower of Asia" to a large portion of the Asian population (Lau et al., 2010) and sediment for associated mega deltas with areas larger than $10000 \mathrm{~km}^{2}$, being home to millions of people (Cruz et al., 2007). Future climate change, as shown in the 5th IPCC assessment report (Masson-Delmotte et al., 2013), will impact the hydrological cycle in this area and consequently the ecology and economy. To define parameters 


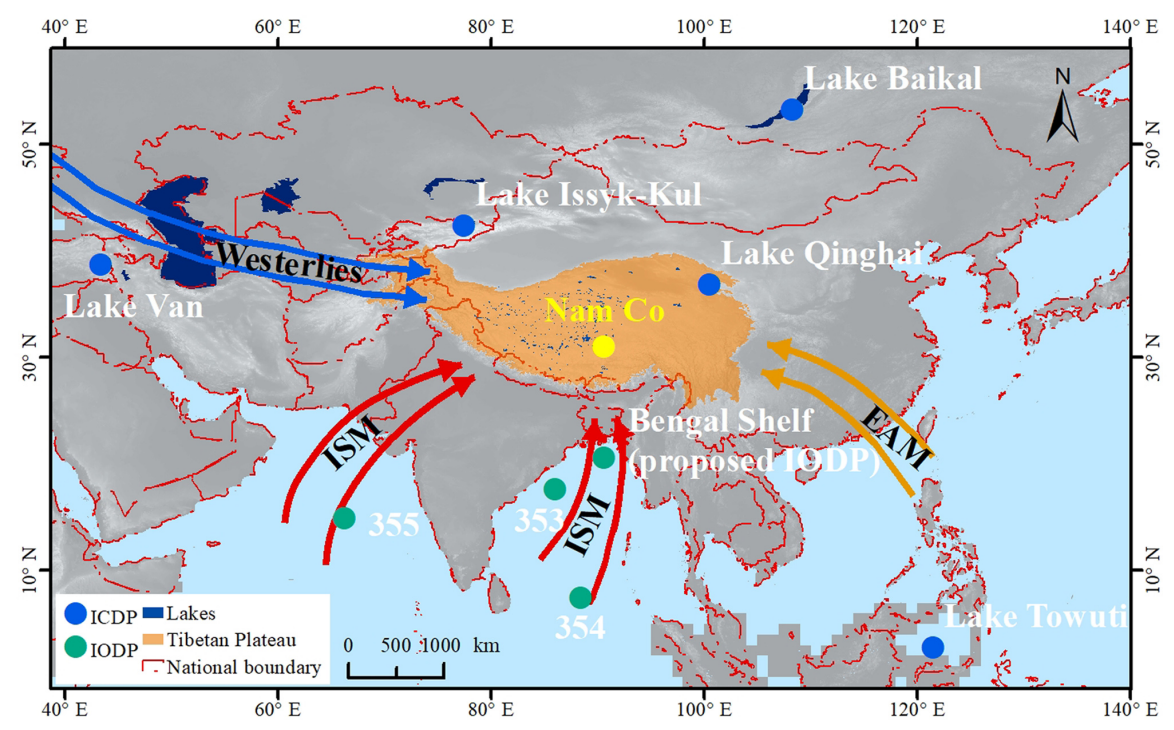

Figure 1. Strategic location of Nam Co (yellow dot) on the Tibetan Plateau (orange area) with respect to further ICDP and IODP sites (blue and green dots). Numbers represent IODP expeditions, ISM: Indian Summer Monsoon, EAM: East Asian Monsoon. Source map: Shuttle Radar Topography Mission digital elevation model (SRTM DEM) from the US Geological Survey (https://lta.cr.usgs.gov/citation, last access: 12 November 2018).

for future climate change scenarios and their consequences for ecosystems and society, it is necessary to improve our knowledge about the thresholds, timing, pace and intensity of past climatic changes and associated environmental impacts, not just on short (modern to Last Glacial Maximum) but also on long geologic timescales and with high resolution.

High-resolution archives, such as lacustrine sediments, are abundant on the Tibetan Plateau but the depositional histories are rather short and often discontinuous, because an arid climate led to repeated desiccation. On the northern TP, Lake Qinghai is an archive where one of the longest paleoclimatic records ( $32 \mathrm{cal} \mathrm{ka} \mathrm{BP}$ ) from the Tibetan Plateau was produced (An et al., 2012). On the western plateau, Bangong $\mathrm{Co}(\mathrm{co}=$ lake $)$ bears a Holocene paleoclimatic record (Fontes et al., 1996) and in the south, at Puma Yumco, paleoclimatic variations of the past $19 \mathrm{cal} \mathrm{kyr} \mathrm{BP}$ were investigated (Nishimura et al., 2014). However, none of these investigations exceeds the Last Glacial. Thus, large and deep lacustrine systems with sizeable catchment areas, integrating regional climatic signals, represent the only suitable continuous paleoclimate archives. Previous studies have shown that Nam Co is one of those lakes (Kasper et al., 2015).

During the past 10 years, transect studies focusing on paleoclimate on the Tibetan Plateau, including Nam Co, have been carried out (Ahlborn et al., 2017; Alivernini et al., 2018; Dietze et al., 2014). In addition, physical and chemical limnological seasonal processes as well as climate parameters at Nam Co have been monitored. Further information on environmental dynamics in the Nam Co catchment is available for glacier dynamics (Bolch et al., 2010), hydrology (Krause et al., 2010), regional geology (Wu et al., 2011), geomorphology (Keil et al., 2010) and meteorology (Ma et al., 2008). This makes the Nam Co area one of the best-surveyed areas on the Tibetan Plateau.

Because of the location of Nam Co on the central Tibetan Plateau at the intersection of westerly and monsoonal air masses (Fig. 1) and its continuous sedimentation history, it represents an ideal drilling target to disentangle long-term changes in climate. A record from Nam Co will enable the following: the relation of climate signals in Tibet to interregional and/or global atmospheric circulation patterns using, for example, sediment cores recovered in IODP; the study of paired ocean and continent archives in appropriate locations with adequate resolution; the investigation of upstream and downstream processes (Thurow et al., 2009) and fill a gap in two ICDP/IODP continental scale transects (Fig. 1, N-S: Lake Baikal, Lake Qinghai, Bay of Bengal; W-E: Lake Van, Lake Issyk-Kul, Lake Towuti). These transects (especially the N-S) will contribute to the Baikal to Bengal transect, which focuses on the internal dynamics of the monsoonal system. This follows previous discussions on utilizing combined ICDP and IODP drilling projects for maximizing the scientific progress in paleoclimate research (Thurow et al., 2009).

\section{Site description}

Nam Co has a flat central basin with a water depth $>95 \mathrm{~m}$ and a smaller and shallower basin of only about $60 \mathrm{~m}$ water depth in the NE (Fig. 2) (Wang et al., 2009). The lake covers 


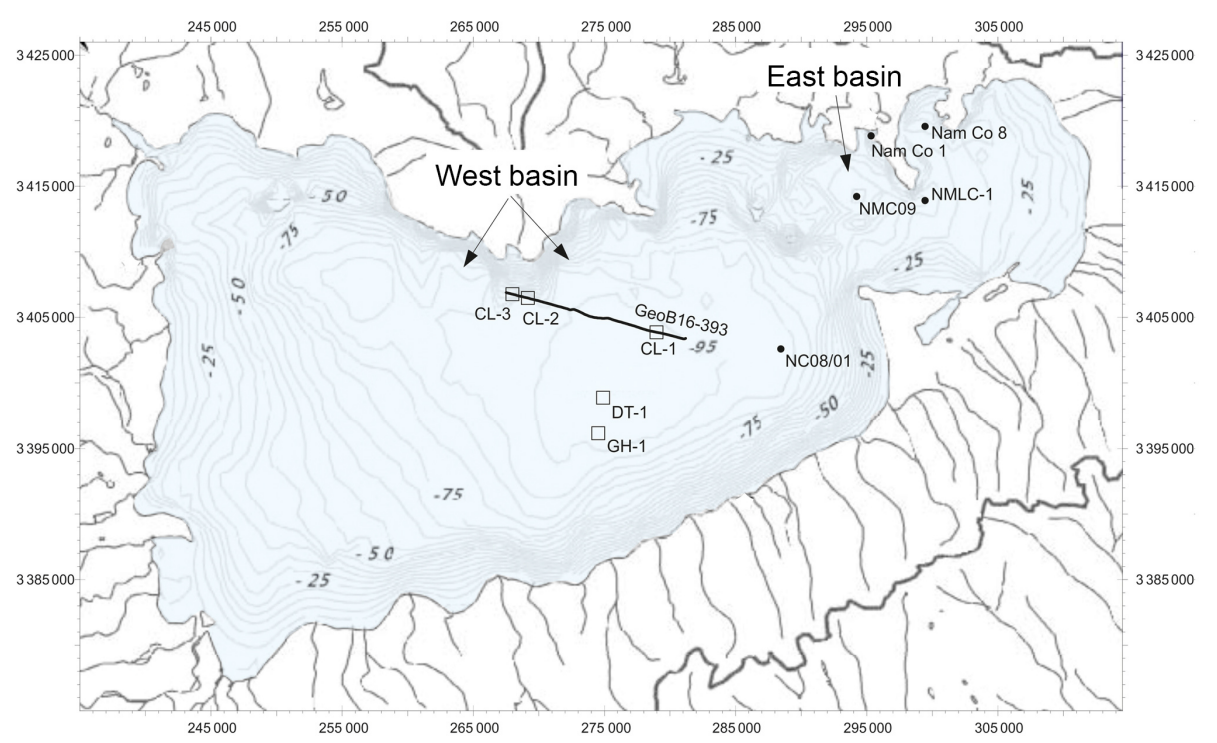

Figure 2. Bathymetry of Nam Co (Wang et al., 2009). Potential drill sites for three piston cores (CL-1, CL-2, CL-3) along profile GeoB16393 (Fig. 4), a deep core (DT-1) and a glacial history core (GH-1) are indicated. Also indicated are previously investigated sediment cores NMLC1 (Zhu et al., 2008), Nam Co 8 (Mügler et al., 2010), NC08/01 (Kasper et al., 2015) and NMC09 (Li et al., 2017).

an area of $2015.4 \mathrm{~km}^{2}$ (Zhu et al., 2010) and has a catchment area of $10680 \mathrm{~km}^{2}$ (Zhou et al., 2013). The drainage area hosts more than 60 streams, most of them draining the glaciated Nyainqêntanglha mountain range ( $>7000 \mathrm{~m}$ a.s.l.) in the S and SW of the lake (Xie et al., 2009). Annual precipitation is around $420 \mathrm{~mm}$, with more than $90 \%$ from intensive monsoonal rainfall from June to September. Dry conditions with low precipitation prevail from October to May (Zhang et al., 2011). As Nam Co is situated in a closed basin, the water balance is primarily controlled by precipitation, evaporation, permafrost glacier meltwater, and groundwater. Annual lake-level fluctuations in the range of $2 \mathrm{~m}$ are clearly related to monsoonal precipitation during summer and evaporation during the rest of the year. Nowadays Nam Co is a dimictic, oligotrophic, slightly alkaline (8.04-9.85, averaging 9.21, Wang et al., 2009) and saline lake $\left(1.851 \mathrm{mS} \mathrm{cm}^{-1}\right.$, Wang et al., 2009) with a waterbody that shows a stable thermal stratification during summer (June to early November) and complete oxygenation throughout the year even during ice coverage (February to mid-May). Allochthonous input by high-density underflows dominates modern sedimentation. The surface distribution patterns of many allochthonous input indicators show that sediment focusing effects occur in the deepest parts of both subbasins.

Nam Co is surrounded by Cretaceous sedimentary rocks as well as Jurassic sediments to the east, and Permian and Carboniferous rocks to the south. Magmatic rocks are found in the northeast of the lake and, together with mainly metamorphic rocks, also form the main part of the glaciated Nyainqêntanglha mountain range in the south (Fig. 3).

Although the main active faults of the Yadong-Gulu rift system lie outside the Nam Co basin (Armijo et al., 1986;
Harrison et al., 1995; Styron et al., 2010), minor faulting may occur across the basin. These faults may be either north-south-trending normal faults or northwest-southeasttrending strike-slip faults or a combination of both. Geology and tectonics (Fig. 3) as well as evidence from own seismic data (Fig. 4) indicate deformation in the Quaternary in the Nam Co basin.

\section{Previous investigations}

High-resolution (centennial to decadal) multiproxy studies on four sediment cores from different water depths and locations (Fig. 2, NMLC1, Zhu et al., 2008; Nam Co 8, Mügler et al., 2010; NC08/01, Kasper et al., 2015; NMC09, $\mathrm{Li}$ et al., 2017) within Nam Co underline the high potential of Nam Co sediments as an environmental archive. Studies integrate results from inorganic geochemistry; sedimentology; mineralogy (Doberschütz et al., 2014); organic geochemistry, including compound-specific ( $n$-alkanes) stable isotopes (Günther et al., 2011); micropaleontological (ostracod and diatom ecology) analyses, including ostracod-based transfer functions (salinity, water depth) and stable isotopes, as well as trace elements from their shells (Yang et al., 2014); paleomagnetic and environmental magnetic investigations (Haberzettl et al., 2015; Kasper et al., 2012; Su et al., 2013); and modern and fossil pollen composition (Zhu et al., 2015).

The longest of the hitherto recovered sediment cores, NC08/01 (10.4 m) from the deepest part of the lake, includes many discoveries made in shorter sediment cores in earlier studies and is therefore used as a reference core. This core covers the past 24 cal kyr BP (Kasper et al., 2015), but high 


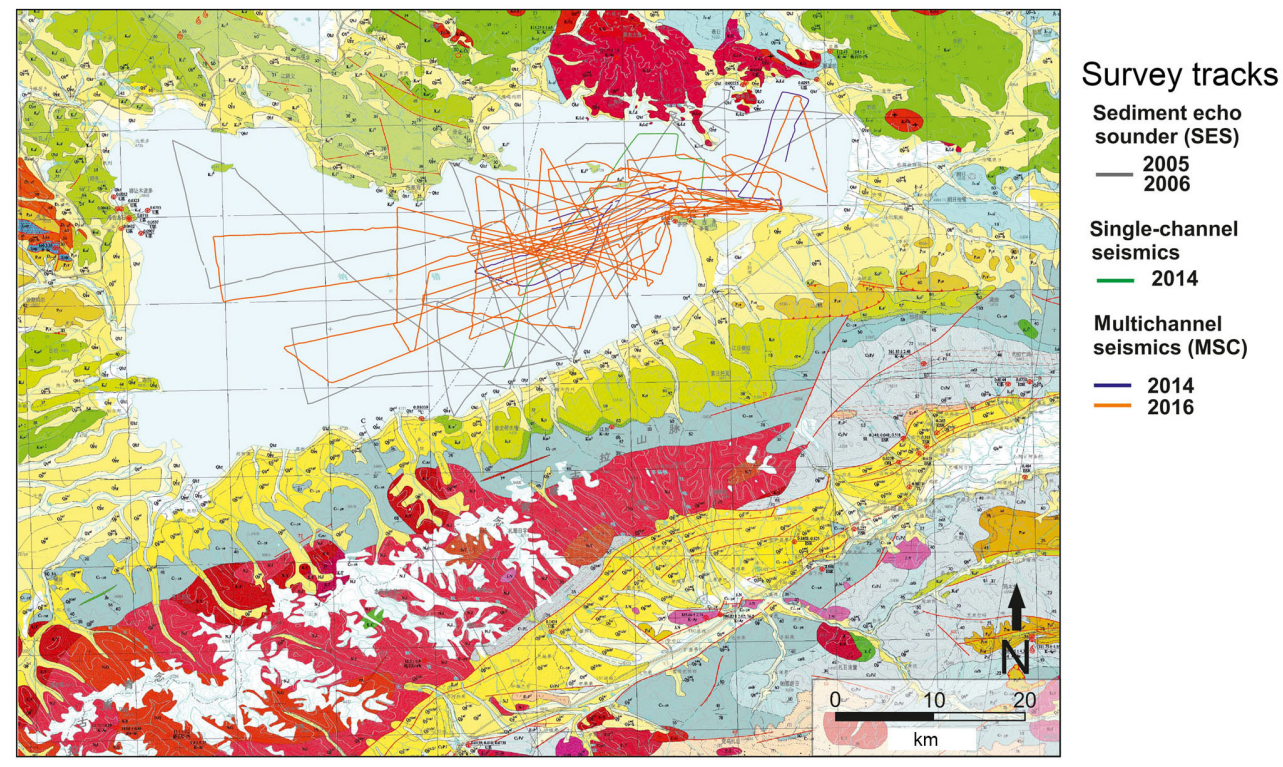

Figure 3. Geological map of the Nam Co area (green: Cretaceous; blue: Jurassic; gray: Permian and Carboniferous; red: magmatic and metamorphic; yellow: Quaternary; white: modern glaciers of the Nyainqêntanglha mountain range) (Wu et al., 2011, modified) and cruise tracks of 2005/2006 echosounder (gray), 2014 single channel (green), and 2014/2016 multichannel seismic surveys (purple and orange).

stand lacustrine deposits up to $139.2 \mathrm{~m}$ above today's lake level of Nam Co, dated back to $115.9 \pm 12.1 \mathrm{ka}$, prove the existence of the lake for a much longer period, potentially as part of an ancient megalake on the Tibetan Plateau (Zhu et al., 2004). In addition, molecular clock analyses of recent endemic gastropods (Radix spp.) occurring in the Nam Co area indicate that their regional diversification started $>1$ Ma ago. This suggests a continuous existence of water bodies in the Nam Co area at least since the middle Pleistocene (von Oheimb et al., 2011).

In 2005 and 2006, about $420 \mathrm{~km}$ of seismic profiles (Fig. 3) was acquired with a parametric sediment echo sounder (Innomar SES 96 light), providing a signal penetration to $30-35 \mathrm{~m}$ sediment depth. After a preliminary deep seismic survey (signal penetration to $\sim 800 \mathrm{~m})$ in $2014(\sim 160 \mathrm{~km})$ an extensive pre-site survey funded by the Deutsche Forschungsgemeinschaft (DFG, German Research Foundation) took place in June-July 2016 to refine the opportunities for a deep drilling ICDP project (Fig. 3). A further goal of this multichannel seismic survey (MCS) was the investigation of the tectonic framework and sedimentary environment to develop stratigraphic and evolutionary scenarios for Nam Co. For this purpose, a micro GI Gun $(2 \times 0.1 \mathrm{~L}$ chamber volume $)$ combined with a multichannel streamer (Teledyne, 32 channels, $64 \mathrm{~m}$ active length) was utilized. In total, 91 deep penetration seismic profiles were recorded, allowing good coverage of the basin $(860 \mathrm{~km})$.

\section{Seismic results}

Seismic profiles reveal at least several hundred meters of sediment infill with varying thicknesses. In the eastern part of the lake a penetration depth of only $250 \mathrm{~ms}$ TWT (twoway travel time) $(\sim 200 \mathrm{~m})$ was reached, whereas the western part allowed a penetration of $>1 \mathrm{~s}$ TWT $(\sim 800 \mathrm{~m})$. Fault patterns in the sediment fill of Nam Co likely represent the predominant regional deformation in the Quaternary. Fig. 4 displays a seismic profile along the NW-SE axis of the lake (GeoB16-393), comprising well-layered sedimentary sequences down to $960 \mathrm{~ms}$ TWT, with densely spaced steep faults, indicating a predominant strike-slip tectonic regime. E-W-trending positive and negative flower structures (Fig. 4) indicate local subsidence and the creation of accommodation space. The interplay of tectonics and sedimentation has apparently maintained a closed basin in the late Quaternary. We suppose that during extensional phases subsidence has significantly influenced sediment accumulation within the basin. Combining the new seismic data and drilling results will provide depositional boundary conditions, e.g. timing of tectonic activity and subsidence rates.

A preliminary seismic stratigraphy was derived using overall reflection strength to distinguish high and low lakelevel settings as well as transitional periods. Also, in MCS data (Fig. 4), low-amplitude seismic facies can be assigned to lake-level high stands and deposition of mostly fine-grained sediments, comparable to the modern situation. A uniform thickness of this uppermost unit is indicative of a widespread deposition of mostly suspended material. During periods of lower lake levels, higher amplitude reflectors indicate coarser 


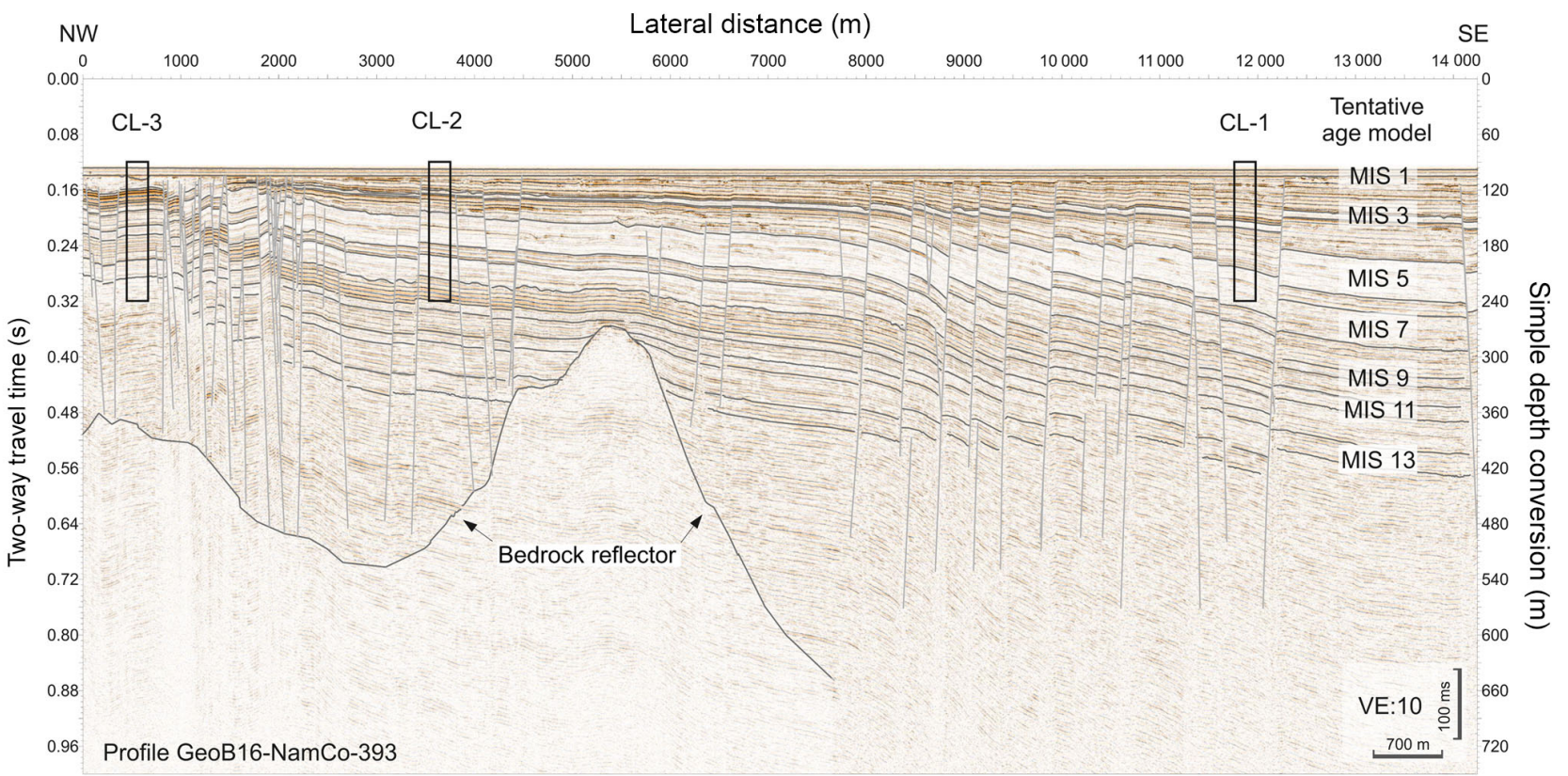

Figure 4. Multichannel seismic profile GeoB16-393 showing several hundred meters of sediment infill. Sediment thickness is increasing towards the center of the lake in the SE due to the additional subsidence of ca. $300 \mathrm{~m}$. Simple depth conversion with $1500 \mathrm{~m} \mathrm{~s}{ }^{-1}$. A tentative age model is given with marine isotope stages (MISs). Potential piston coring locations (CL-1, CL-2, CL-3) at which sediment cores can well be parallelized to form a composite sediment sequence using strong reflectors in the seismic images are indicated by black boxes.

material. This and minor incisions in shallower parts of the lake as well as irregular topography hint to erosion in a shallow lake. In Fig. 4 extrapolation of the sedimentation rates and the acoustic behavior observed in the reference core confirm that at least 13 MIS stages are imaged (Fig. 4), with older sedimentary sections present.

\section{Workshop}

With these data in mind 40 scientists from 13 countries, representing various fields, met in Beijing from 22 to 24 May 2018 to discuss the further scientific opportunities that an ICDP drilling effort would provide. In addition, drilling strategies as well as logistical requirements of a deep drilling at Nam Co were discussed. Contributions of the participants included the following topics:

- the tectonic setting of $\mathrm{Nam} \mathrm{Co}$;

- the global relevance of a long climate record from Nam Co;

- paleoclimatological work which had been and will be carried out at Nam Co;

- seismic stratigraphy of Nam Co;

- archives for comparison;

- lake drilling project management, drilling operations, and fundamental core analyses;
- geochronology;

- bioindicators and deep biosphere;

- downhole logging;

- paleomagnetism;

- provenance analyses.

In addition, an excursion to Nam Co was planned for late 2018 to consider possible lake access points and base camps for future drilling and science teams as well as other logistic challenges.

Several discussion groups were organized to focus on the themes noted above and were charged with writing short reports to identify the major questions and develop hypotheses that will be addressed by studying Nam Co sediments through an ICDP deep drilling project. These groups included (1) sedimentology, (2) pollen, (3) bioindicators, (4) chronology and (5) tectonics. Scientific hypotheses were subsequently reviewed by all workshop participants and revisited by the breakout groups on the last day of the workshop. This reiterating process led to scientific hypotheses which can be tested by scientific drilling, such as the following for example:

- The timing and magnitude of Indian monsoon variability is controlled by eccentricity- and/or precessiondriven insolation during the last million years. 
- The land-ocean temperature gradient is greatest in transitions from terminations to interglacials, increasing precipitation (decreasing evaporation/inflow).

- Hemispheric climate controls species diversity, functional diversity and evolution of high-altitude ecosystems during the last $1 \mathrm{Ma}$.

- Aquatic and terrestrial biomes respond independently to environmental forcing over multiple glacial to interglacial cycles.

- High-altitude ecosystems are resilient from interglacial to interglacial which results in similar community structures and functions.

- The activity and diversity of the subsurface biosphere in high-altitude lake basins is dependent on their relationship to climate-driven carbon cycling and nutrient availability.

- The permanent lake system of Nam Co provided a refugium during glacials and, due to its unique location and size, was instrumental in the survival and recolonization of high-altitude species endemic to the Tibetan Plateau.

- The denudation rate of the Nyainqêntanglha mountain range controls sediment accumulation in the closed Nam Co basin.

- Deformation in the basin is consistent in space and time with regional tectonics.

These hypotheses will be used and revisited for the preparation of an ICDP full proposal. Participants saw dating as the most important prerequisite to be able to test the abovementioned hypotheses. It was concluded that 200 radiocarbon ages in combination with 200-400 OSL ages will provide a sound chronology for the younger part of the sequence, allowing the "calibration" of the paleomagnetic signal which should be used to date the older part. The use of U-Th dating as another dating technique was seen as questionable as more recent sediments showed a high detrital Th component. Therefore, the use of U-Th as an additional dating technique will have to be tested for older sediments. Amino acid dating might also be used for dating if suitable material can be extracted from the sediment sequence.

The last part of the workshop was dedicated to drilling strategies, on-site work and budgeting as well as outreach opportunities. Since Nam Co is characterized by ongoing tectonism, new accommodation space is constantly created in different parts of the lake. As this is a "quasi" continuous process, younger sediments are found at the top of the sequences in the southern part and older sediments at the top of the sequences in the northern part, with intermediate sequences in between (Fig. 4). Considering this architecture, one promising drilling strategy which was discussed by the participants was to build a composite record using three to four overlapping cores in rather high resolution and of good quality, recovered from different sites (Fig. 4). Using, for example, three to four $100-150 \mathrm{~m}$ long piston cores (e.g. CL-1 to 3 in Fig. 4) in a N-S transect a continuous, high-core-quality composite sequence going back to MIS 13 (according to the seismic interpretation) will be obtained. These sites should be covered by triple cores. The construction of a continuous log will be improved by downhole logging data. Also possible depth shifts will be corrected using these data. This composite record will be complemented by a $\sim 700-800 \mathrm{~m}$ long core (DT-1 in Fig. 2) going back to $\sim 1$ Ma which most likely can only be cored as a single hole due to time constraints. Modern process studies show that different subbasins of Nam Co show different signals. For example, oxygen isotopes reveal an offset of $2 \%$ o between basins. Thus, the long core will be used to calibrate signal changes in proxies detected in the high-quality "short" piston cores. Finally, two $\sim 100 \mathrm{~m}$ parallel cores forming the composite sequence GH-1 will be recovered from the very southern shore (Fig. 2) in order to investigate the role of glacial activity and its impact on the lake. The ICDP's Deep Lake Drilling System was generally seen as a reasonable tool for drilling Nam Co as it has been successfully applied to other challenging environmental systems (e.g. the Dead Sea in Israel).

Since Nam Co is located at an altitude of $4730 \mathrm{~m}$ a.s.l. there was intense discussion of how much man power will be needed to guarantee a smooth drilling operation. Everybody agreed that on-site work should at least include measurements of magnetic susceptibility and density to calculate porosity, which is important for OSL dating, using a MultiSensor Core Logger (MSCL). A mobile nuclear magnetic resonance (NMR) device will enable water content and thus porosity to be even more precisely determined. This will be complemented by pore water extraction and a clean lab for microbiological investigations. If manpower permits microscopes could also potentially be set up on-site.

\section{Conclusions}

All participants agreed that Nam Co sediments hold an extraordinary potential to answer questions of global social relevance, including past, modern and future climate change, biological development, tectonic evolution, and understanding of paleomagnetic variations and water resources which are coupled to the hydrological cycle. The workshop allowed the refinement of the scientific questions and discussion of the logistical issues of a scientific drilling of Nam Co in the framework of ICDP. Moreover, it allowed the transfer of knowledge between the different participants, increasing international visibility and promoting multidisciplinarity.

Data availability. No data sets were used in this article. 
Team list. Guillaume St-Onge (University of Quebec, Rimouski, Canada), Fahu Chen (Institute of Tibetan Plateau Research, CAS, Beijing, China), Xingqi Liu (Beijing Normal University, Beijing, China), Xinmiao Lyu (Institute of Tibetan Plateau Research, CAS, Beijing, China), Jianting Ju (Institute of Tibetan Plateau Research, CAS, Beijing, China), Qingfeng Ma (Institute of Tibetan Plateau Research, CAS, Beijing, China), Zhonghai Wu (Chinese Academy of Geological Sciences, Beijing, China), Bernd Wünnemann (East China Normal University, Shanghai, China), Dada Yan (East China Normal University, Shanghai, China), Shuangwen Yi (Nanjing University, Nanjing, China), Hanzhi Zhang (Nanjing University, Nanjing, China), Yan Zhao (Institute of Geographic Sciences and Natural Resources Research, CAS, Beijing, China), Hongbo Zhao (China Geological Survey (Beijing Institute of Exploration Engineering), Bejing, China), Jan-Pieter Buylaert (Aarhus University, Aarhus, Denmark), Andrew Murray (Aarhus University, Aarhus, Denmark), Jerome van der Woerd (University of Strasbourg, Strasbourg, France), Peter Frenzel (Friedrich-SchillerUniversity, Jena, Germany), Gerd Gleixner (MPI Jena, Germany), Uli Harms (Scientific Drilling Operational Support Group ICDP, Potsdam, Germany), Klaus Reicherter (RWTH Aachen University, Aachen, Germany), Antje Schwalb (Technische Universität Braunschweig, Braunschweig, Germany), Arne Ulfers (Leibniz Institute for Applied Geophysics (LIAG), Hanover, Germany), Gábor Újvári (Research Centre for Astronomy and Earth sciences, Hungarian Academy of Sciences, Budapest, Hungary), Nivedita Mehrotra (Birbal Sahni Institute of Palaeosciences, Lucknow, India), Nicolas Waldmann (University of Haifa, Haifa, Israel), Andrea Lami (Italian National Research Council, Rome, Italy), Daniel Ariztegui (University of Geneva, Geneva, Switzerland), Natasha Barbolini (University of Amsterdam, Amsterdam, the Netherlands), Philippa Ascough (Scottish Universities Environmental Research Centre, East Kilbride, UK), Leon Clarke (Manchester Metropolitan University, Manchester, UK), Andrew Henderson (Newcastle University, Newcastle upon Tyne, UK), Richard Staff (Scottish Universities Environmental Research Centre, East Kilbride, UK), Anders Noren (LacCore Facility, University of Minnesota, Minneapolis, USA), Trisha Spanbauer (University of Texas at Austin, Austin, USA), Joseph Stoner (Oregon State University, Corvallis, USA).

Author contributions. All authors jointly organized the workshop. TH drafted the paper and NS drafted Figs. 2 to 4 . All coauthors jointly contributed to the content of the final version of the paper. Listed workshop participants enthusiastically discussed the scientific objectives of a scientific drilling at Nam Co, contributed to the compilation of the hypotheses listed above and commented on the paper.

Competing interests. The authors declare that they have no conflict of interest.

Acknowledgements. We would like to acknowledge funding from ICDP and the Institute of Tibetan Plateau Research to carry out the workshop in Beijing. We would also like to thank Thomas Kasper and Ruimin Yang for drafting Fig. 1.
Edited by: Ulrich Harms

Reviewed by: two anonymous referees

\section{References}

Ahlborn, M., Haberzettl, T., Wang, J., Henkel, K., Kasper, T., Daut, G., Zhu, L., and Mäusbacher, R.: Synchronous pattern of moisture availability on the southern Tibetan Plateau since $17.5 \mathrm{cal}$. ka BP-the Tangra Yumco lake sediment record, Boreas, 46, 229241, 2017.

Alivernini, M., Akita, L. G., Ahlborn, M., Börner, N., Haberzettl, T., Kasper, T., Plessen, B., Peng, P., Schwalb, A., Wang, J., and Frenzel, P.: Ostracod-based reconstruction of Late Quaternary lake level changes within the Tangra Yumco lake system (southern Tibetan Plateau), J. Quaternary Sci., 33, 713-720, 2018.

An, Z., Colman, S. M., Zhou, W., Li, X., Brown, E. T., Jull, A. J. T., Cai, Y., Huang, Y., Lu, X., Chang, H., Song, Y., Sun, Y., Xu, H., Liu, W., Jin, Z., Liu, X., Cheng, P., Liu, Y., Ai, L., Li, X., Liu, X., Yan, L., Shi, Z., Wang, X., Wu, F., Qiang, X., Dong, J., $\mathrm{Lu}, \mathrm{F}$., and $\mathrm{Xu}, \mathrm{X}$. .: Interplay between the Westerlies and Asian monsoon recorded in Lake Qinghai sediments since $32 \mathrm{ka}$, Nat. Sci. Rep., 2, 1-6, 2012.

Armijo, R., Tapponnier, P., Mercier, J., and Han, T. L.: Quaternary extension in southern Tibet: Field observations and tectonic implications, J. Geophys. Res.-Sol. Ea., 91, 13803-13872, 1986.

Bolch, T., Yao, T., Kang, S., Buchroithner, M. F., Scherer, D., Maussion, F., Huintjes, E., and Schneider, C.: A glacier inventory for the western Nyainqentanglha Range and the Nam Co Basin, Tibet, and glacier changes 1976-2009, The Cryosphere, 4, 419433, https://doi.org/10.5194/tc-4-419-2010, 2010.

Cruz, R. V., Harasawa, H., Lal, M., Wu, S., Anokhin, Y., Punsalmaa, B., Honda, Y., Jafari, M., Li, C., and Huu Ninh, N.: Asia - Climate Change 2007: Impacts, Adaptation and Vulnerability, Contribution of Working Group II to the Fourth Assessment Report of the Intergovernmental Panel on Climate Change, Cambridge, 469-506, 2007.

Dietze, E., Maussion, F., Ahlborn, M., Diekmann, B., Hartmann, K., Henkel, K., Kasper, T., Lockot, G., Opitz, S., and Haberzettl, T.: Sediment transport processes across the Tibetan Plateau inferred from robust grain-size end members in lake sediments, Clim. Past, 10, 91-106, https://doi.org/10.5194/cp-10-91-2014, 2014.

Doberschütz, S., Frenzel, P., Haberzettl, T., Kasper, T., Wang, J., Zhu, L., Daut, G., Schwalb, A., and Mäusbacher, R.: Monsoonal forcing of Holocene paleoenvironmental change on the central Tibetan Plateau inferred using a sediment record from Lake Nam Co (Xizang, China), J. Paleolimnol., 51, 253-266, 2014.

Fontes, J.-C., Gasse, F., and Gibert, E.: Holocene environmental changes in Lake Bangong basin (Western Tibet), Part 1: Chronology and stable isotopes of carbonates of a Holocene lacustrine core, Palaeogeogr. Palaeocl., 120, 25-47, 1996.

Günther, F., Mügler, I., Mäusbacher, R., Daut, G., Leopold, K., Gerstmann, U. C., Xu, B., Yao, T., and Gleixner, G.: Response of $\delta \mathrm{D}$ values of sedimentary $\mathrm{n}$-alkanes to variations in source water isotope signals and climate proxies at lake Nam Co, Tibetan Plateau, Quatern. Int., 236, 82-90, 2011.

Haberzettl, T., Henkel, K., Kasper, T., Ahlborn, M., Su, Y., Wang, J., Appel, E., St-Onge, G., Stoner, J., Daut, G., Zhu, L., and Mäusbacher, R.: Independently dated paleomagnetic secular variation 
records from the Tibetan Plateau, Earth Planet. Sc. Lett., 416, 98-108, 2015.

Harrison, T. M., Copeland, P., Kidd, W., and Lovera, O. M.: Activation of the Nyainqentanghla shear zone: Implications for uplift of the southern Tibetan Plateau, Tectonics, 14, 658-676, 1995.

Kasper, T., Haberzettl, T., Doberschütz, S., Daut, G., Wang, J., Zhu, L., Nowaczyk, N., and Mäusbacher, R.: Indian Ocean Summer Monsoon (IOSM)-dynamics within the past 4 ka recorded in the sediments of Lake Nam Co, central Tibetan Plateau (China), Quaternary Sci. Rev., 39, 73-85, 2012.

Kasper, T., Haberzettl, T., Wang, J., Daut, G., Zhu, L., and Mäusbacher, R.: Hydrological variations on the Central Tibetan Plateau since the LGM and their teleconnection to inter-regional and hemispheric climate variations, J. Quaternary Sci., 30, 7078, 2015.

Keil, A., Berking, J., Mügler, I., Schütt, B., Schwalb, A., and Steeb, P.: Hydrological and geomorphological basin and catchment characteristics of Lake Nam Co, South-Central Tibet, Quatern. Int., 218, 118-130, 2010.

Krause, P., Biskop, S., Helmschrot, J., Flügel, W. A., Kang, S., and Gao, T.: Hydrological system analysis and modelling of the Nam Co basin in Tibet, Adv. Geosci., 27, 29-36, 2010.

Lau, W. K. M., Kim, M. K., Kim, K. M., and Lee, W. S.: Enhanced surface warming and accelerated snow melt in the Himalayas and Tibetan Plateau induced by absorbing aerosols, Environ. Res. Lett., 5, 025204, https://doi.org/10.1088/1748-9326/5/2/025204, 2010.

Li, C., Yan, F., Kang, S., Chen, P., Han, X., Hu, Z., Zhang, G., Hong, Y., Gao, S., Qu, B., Zhu, Z., Li, J., Chen, B., and Sillanpää, M.: Re-evaluating black carbon in the Himalayas and the Tibetan Plateau: concentrations and deposition, Atmos. Chem. Phys., 17, 11899-11912, https://doi.org/10.5194/acp-17-118992017, 2017.

Ma, Y., Kang, S., Zhu, L., Xu, B., Tian, L., and Yao, T.: ROOF OF THE WORLD: Tibetan Observation and Research Platform, B. Am. Meteorol. Soc., 89, 1487-1492, 2008.

Masson-Delmotte, V., Schulz, M., Abe-Ouchi, A., Beer, J., Ganopolski, A., Rouco, J. F. G., Jansen, E., Lambeck, K., Luterbacher, J., Naish, T., Osborn, T., Otto-Bliesner, B., Quinn, T., Ramesh, R., Rojas, M., Shao, X., and Timmermann, A.: Information from Paleoclimate Archives, Cambridge, New York, 2013.

Mügler, I., Gleixner, G., Günther, F., Mäusbacher, R., Daut, G., Schütt, B., Berking, J., Schwalb, A., Schwark, L., Xu, B., Yao, T., Zhu, L., and Yi, C.: A multi-proxy approach to reconstruct hydrological changes and Holocene climate development of Nam Co, Central Tibet, J. Paleolimnol., 43, 625-648, 2010.

Nishimura, M., Matsunaka, T., Morita, Y., Watanabe, T., Nakamura, T., Zhu, L., Nara, F. W., Imai, A., Izutsu, Y., and Hasuike, K.: Paleoclimatic changes on the southern Tibetan Plateau over the past 19,000 years recorded in Lake Pumoyum Co, and their implications for the southwest monsoon evolution, Palaeogeogr. Palaeocl., 396, 75-92, 2014.

Qiu, J.: China: The third pole, Nature, 454, 393-396, 2008.

Styron, R., Taylor, M., and Okoronkwo, K.: Database of active structures from the Indo-Asian collision, Eos T. Am. Geophys. Un., 91, 181-182, 2010.

Su, Y., Gao, X., Liu, Q., Hu, P., Duan, Z., Jiang, Z., Wang, J., Zhu, L., Doberschütz, S., Mäusbacher, R., Daut, G., and Haberzettl, T.: Mechanism of variations in environmental magnetic prox- ies of lake sediments from Nam Co, Tibet during the Holocene, Chin. Sci. Bull., 58, 1568-1578, 2013.

Thurow, J., Peterson, L. C., Harms, U., Hodell, D. A., Cheshire, H., Brumsack, H.-J., Irino, T., Schulz, M., Masson-Delmotte, V., and Tada, R.: Acquiring High to Ultra-High Resolution Geological Records of Past Climate Change by Scientific Drilling, Sci. Dril., 8, 46-56, https://doi.org/10.2204/iodp.sd.8.08.2009, 2009.

von Oheimb, P. V., Albrecht, C., Riedel, F., Du, L. N., Yang, J. X., Aldridge, D. C., Bossneck, U., Zhang, H. C., and Wilke, T.: Freshwater Biogeography and Limnological Evolution of the Tibetan Plateau - Insights from a Plateau-Wide Distributed Gastropod Taxon (Radix spp.), Plos One, 6, e26307, https://doi.org/10.1371/journal.pone.0026307, 2011.

Wang, J., Zhu, L., Daut, G., Ju, J., Lin, X., Wang, Y., and Zhen, X.: Investigation of bathymetry and water quality of Lake Nam Co, the largest lake on the central Tibetan Plateau, China, Limnology, 10, 149-158, 2009.

Wu, Z. H., Meng, X. G., and Hu, D. G.: Regional Geological Survey Report of China (Damxong), China University of Geosciences Press, Wuhan, China, 346 pp., 2011.

Xie, M., Zhu, L., Peng, P., Wang, J., Wang, Y., and Schwalb, A.: Ostracod assemblages and their environmental significance from the lake core of the Nam Co on the Tibetan Plateau 8.4 ka BP, J. Geogr. Sci., 19, 387-402, 2009.

Yang, Q., Jochum, K. P., Stoll, B., Weis, U., Börner, N., Schwalb, A., Frenzel, P., Scholz, D., Doberschütz, S., Haberzettl, T., Gleixner, G., Mäusbacher, R., Zhu, L., and Andreae, M. O.: Trace element variability in single ostracod valves as a proxy for hydrochemical change in Nam Co, central Tibet, during the Holocene, Palaeogeogr. Palaeocl., 399, 225-235, 2014.

Zhang, Y. J., Kang, S. C., and You, Q. L.: Climate in Nam Co Basin, in: Modern Environmental Processes and Changes in the Nam Co Basin Tibetan Plateau, edited by: Kang, S. C., China Meteorological Press, 15-35, 2011.

Zhou, S., Kang, S., Chen, F., and Joswiak, D. R.: Water balance observations reveal significant subsurface water seepage from Lake Nam Co, south-central Tibetan Plateau, J. Hydrol., 491, 89-99, 2013.

Zhu, D. G., Meng, X. G., Zhao, X. T., Shao, Z. G., Xu, Z. F., Yang, C. B., Ma, Z. B., Wu, Z. G., Wu, Z. H., and Wang, J. P.: Evolution of an Ancient Large Lake in the Southeast of the Northern Tibetan Plateau, Acta Geol. Sin.-Engl., 78, 982-992, 2004.

Zhu, L., Wu, Y., Wang, J., Lin, X., Ju, J., Xie, M., Li, M., Mäusbacher, R., Schwalb, A., and Daut, G.: Environmental changes since $8.4 \mathrm{ka}$ reflected in the lacustrine core sediments from Nam Co, central Tibetan Plateau, China, The Holocene, 18, 831-839, 2008.

Zhu, L., Peng, P., Xie, M., Wang, J., Frenzel, P., Wrozyna, C., and Schwalb, A.: Ostracod-based environmental reconstruction over the last 8,400 years of Nam Co Lake on the Tibetan plateau, Hydrobiologia, 648, 157-174, 2010.

Zhu, L., Lü, X., Wang, J., Peng, P., Kasper, T., Daut, G., Haberzettl, T., Frenzel, P., Li, Q., Yang, R., Schwalb, A., and Mäusbacher, R.: Climate change on the Tibetan Plateau in response to shifting atmospheric circulation since the LGM, Sci. Rep., 5, 13318, https://doi.org/10.1038/srep13318, 2015. 